\title{
The Study on the Optimization of Container Multimodal Transport Business Process in Shandong
}

\author{
Fengmei Wang ${ }^{1, *}$, Xiaoyi Gong ${ }^{1}$, Yingying $\mathrm{Ni}^{1}{ }^{1}$ Jun Zhan $^{1}$, and Huiping Che ${ }^{1}$ \\ ${ }^{1}$ Shan dong Jiao tong University, Ji nan, Shan dong, China
}

\begin{abstract}
Shandong is a coastal city with good location advantages. As a hub port for international trade goods and a port of transhipment, shandong's demand for multimodal transport is more urgent. By selecting the suitable non-water port and the multimodal transport carrier to improve the efficiency of multimodal transport, the purpose of saving the time of logistics is achieved, thus reducing the logistics cost.It branch out through Shandongt, and it can reach the central region of China, can reach the Western remote area, too. This paper puts forward the optimization scheme of the business process of container multimodal transport. The optimization of freight forwarding business process is analyzed. The multimodal transport model in Shandong was designed. Finally, the optimal approach of multimodal transport in Shandong is put forward.
\end{abstract}

\section{Introduction}

The container multimodal transport is an advanced form of transport organization in comprehensive cargo transport. It is organized in the form of a container as a transport unit, combining the different modes of transport with units to form a continuous and comprehensive integrated transport of goods. The socalled "organic combination of different modes of transport" is the focus of the integrated freight transport system, which effectively connects the different modes of transport through containers, so that the whole process can be integrated through containers, realize the efficiency and integrity of the transport products, and form a truly comprehensive cargo. Container multimodal transport is the key to solve the bottleneck of China's comprehensive transport services. Now, the state has put forward the "Belt and Road" and other policy support, Container multimodal transport has received unprecedented attention and has become the trend of logistics industry development in our country.

\section{Container multimodal transport business process in Shandong}

At present, the Shandong region is slower than the sea rail transport, but the development potential is greater. The port development of the sea rail transport will help to promote the expansion of the port throughput and the development of the port industry, and also help to transform the port to the diversified ports, which is beneficial to the long-term development of the port.[1] In addition, the Fifth China multimodal transport cooperation and development conference clearly shows that the link between the railway and the port is an important trend in the future. Therefore, it is a necessary direction and an important opportunity for the Shandong region to focus on the development of the sea rail joint transport.

Take the example of the exportation of the sea rail link. The shipper sends a consignment application, the multimodal transport operator (the freight forwarder) accepts and signed a multimodal transport contract with it. After that, it makes a rational use of the box plan, reservations to the railway department, and arranges for the application, extraction and delivery of empty boxes by the highway transportation enterprises;and the cargo is made to the shipping company, then the cargo owner is ready to stock up and pay more. The owner after delivery (or by forwarding instead) sent to the office of departure from the customs surveillance zone, sealing clearance. They are transported to the railway container freight station by container trucks, marshalling, loading and Issuing the waybill, and pay the first carrier (railway carrier). After the railway line for long-distance transportation to the railway container marshalling station, and then sent to the railway container freight station, and delivery of goods. The cargo is packed into port and transported to the rear yard of the port. The second carrier (Sea Carrier) is responsible for maritime transport, and the bill of lading is issued after shipment and the multimodal carrier is paid.

During the course of the sea rail transport business, the multimodal transport operator is responsible for the entire transportation process, including participating in the shipping company, handling the secondary school procedures, issuing and delivering the bill of lading and so on. The specific sea rail transport business process is shown in Figure 1.

\footnotetext{
* Corresponding author: 1423185475@qq.com
} 


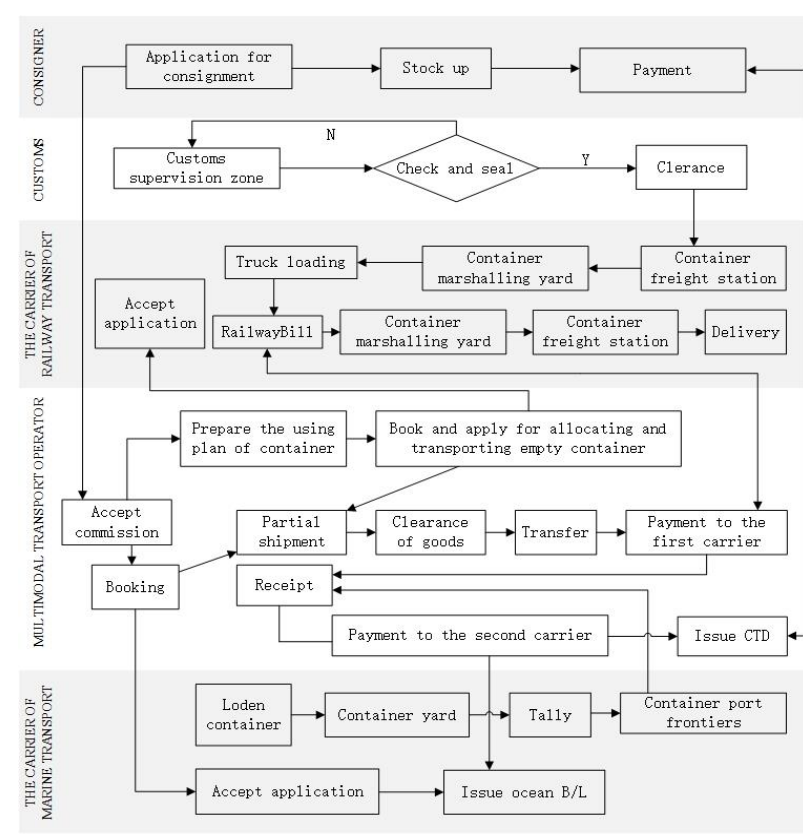

Fig.1. Export flow chart of sea rail multimodal transportation.

Besides, business process optimization needs policy guidance. Taking Qingdao port as an example, compared with ports such as Lianyungang, Tianjin Xingang, the transport distance is longer and the freight rate is higher. In the fierce competition of logistics market, price competitiveness is one of the important factors of port development. In view of Qingdao port, Rizhao Port and other ports with certain supply and location advantages, we can appropriately increase policy and financial support.

(1) Subsidize the costs of the two ends of the rail transport (railway station and port loading and unloading, storage, and port short-term berth) to reduce the cost of comprehensive transport of customers.

(2) Give tax relief to port enterprises.

(3) The export source of China's coastal ports is about 1.6 times as much as the import source, and the internal and external trade structure is very different. In addition, the unequal flow of the goods is caused by the unequal factors of regional economic development. Accordingly, we can directly subsidize the shipping companies and railway enterprises to make up for the uneven of ports. [2]

(4) In terms of short distance transportation, sea rail intermodal transport and intermodal transport still have no advantages. In particular, there are some unreasonable subsidies to highway transportation, which leads to the lack of advantages of the sea rail transport in the comprehensive freight rate. Through the policy adjustment, it can attract the medium and short distance goods and promote the development of the sea rail transport.

\section{Business process optimization of freight forwarders}

Freight forwarding enterprises undertake the importance of connecting all transportation links in the process of multimodal transport. While most of the companies are smaller and less competitive, they can achieve cooperation and win-win cooperation on through the establishment of alliance groups through business division and information sharing. The consortium business process is shown in Figure 2.

\begin{tabular}{|c|c|c|c|c|c|c|}
\hline $\begin{array}{c}\text { The division of } \\
\text { business }\end{array}$ & encasement & $\begin{array}{l}\text { Loden } \\
\text { container }\end{array}$ & declaration & $\begin{array}{l}\text { Clearance of } \\
\text { goods }\end{array}$ & \multicolumn{2}{|c|}{$\begin{array}{l}\text { Sign and } \\
\text { issue } B / L\end{array}$} \\
\hline Consigner A & & & & & & \\
\hline Consigner $B$ & & \multicolumn{2}{|c|}{$\begin{array}{l}\text { FORWARDER } \\
\text { ALLIANCE }\end{array}$} & & \multicolumn{2}{|c|}{ Customs } \\
\hline Consigner $\mathrm{C}$ & & & & & \multicolumn{2}{|c|}{$\begin{array}{l}\text { Shipping } \\
\text { company }\end{array}$} \\
\hline $\begin{array}{l}\text { Information } \\
\text { sharing }\end{array}$ & \multicolumn{2}{|c|}{$\begin{array}{c}\text { Distribution requirements } \\
\text { planning }\end{array}$} & $\begin{array}{l}\text { Transport } \\
\text { planning }\end{array}$ & $\begin{array}{l}\text { Loading a } \\
\text { unloading } \mathrm{p}\end{array}$ & & ....... \\
\hline
\end{tabular}

Fig.2. The operation flow chart of forwarder alliance.

In the process of multimodal transport, receive and collect the consignment, due to the train or ship shipping space, or yard, loading and unloading the goods at the factory, to the station or the ship generation to handle the declaration, issued a bill of lading, submitted to the customs and other business carriers on the reasonable division of labor. And sharing the information

of distribution plan, transportation plan, loading and unloading plan, customer demand information, loading and unloading plan, market demand forecast and so on, can efficiency of the consortium. By concentrating the volume of the same route of each company to get the tariff preference and priority of loading and unloading,it can reduce the customer's comprehensive freight rate and effectively reduce the transportation time. In addition, on the basis of the establishment of the alliance, the freight forwarders can promote the coordinated development of the logistics supply chain more quickly.

\section{Design of multimodal transport mode in Shandong area}

The container transport dominated by railways and highways and foreign trade container transport dominated by sea are linked together by multimodal transport. [3] The multimodal transport process involves many principals, including suppliers, multimodal transport operators,customers, agents,segment carriers and customs inspection and other individuals.

Take a Shandong intermodal company as an example, The establishment of business outlets in the economic hinterland, the inland port is responsible for the transfer, the headquarters is responsible for the coordination and freight settlement mode. The division of business of general company, branch company and inland port company is shown in Table 1 . 
Table 1. The division of individual and business of a company in Shandong.

\begin{tabular}{|c|c|}
\hline $\begin{array}{l}\text { Name of } \\
\text { individual }\end{array}$ & Business divisions \\
\hline \multirow{2}{*}{$\begin{array}{l}\text { Shandong } \\
\text { local } \\
\text { multimodal } \\
\text { transport } \\
\text { corporation }\end{array}$} & The organizer of the through carriage. \\
\hline & $\begin{array}{l}\text { Coordinate with transportation department } \\
\text { and settlement of freight with all } \\
\text { transportation departments. }\end{array}$ \\
\hline \multirow{4}{*}{$\begin{array}{l}\text { Branch } \\
\text { office }\end{array}$} & $\begin{array}{l}\text { To organize and handle multimodal } \\
\text { transport of goods. }\end{array}$ \\
\hline & $\begin{array}{l}\text { Hand over and take over goods at local road } \\
\text { station. }\end{array}$ \\
\hline & Issue of multimodal transport documents. \\
\hline & Collect full road, rail and sea freight. \\
\hline $\begin{array}{l}\text { Inland port } \\
\text { company }\end{array}$ & $\begin{array}{l}\text { Coordination "one customs and three } \\
\text { inspections(custons: commodity inspection, } \\
\text { animal and plant inspection, sanitary } \\
\text { inspection)" }\end{array}$ \\
\hline
\end{tabular}

In this mode, relying on the perfect information system of the logistics center, the effective link between the inland port and the short road transportation of the railway container can be realized. And the container from the road trailer to the railway vehicle can be transferred directly. The storage time of the container is compressed in the port and the whole logistics of the container door to the door will be saved. And the profits of the enterprises and the society are added up. [4]

The specific operational processes can be represented in Figure 3 and Table 2.

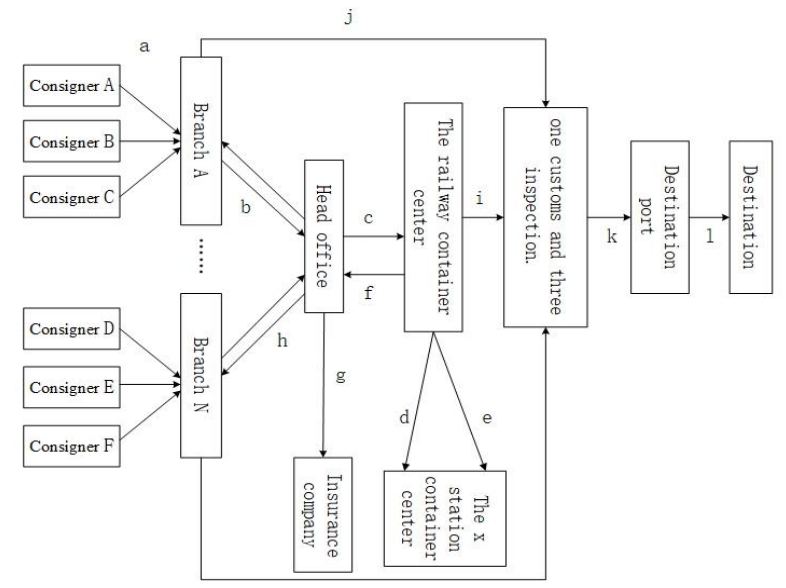

Fig.3. The Flow chart of multimodal transportation.
Table 2. The meaning of each order number.

\begin{tabular}{|c|c|}
\hline $\begin{array}{c}\text { order } \\
\text { num } \\
\text { ber }\end{array}$ & Meaning \\
\hline $\mathrm{a}$ & $\begin{array}{l}\text { Each branch office collects the source } \\
\text { information in the economic hinterland and } \\
\text { summarizes the information, conclude a } \\
\text { multimodal transport contract, collects freight. }\end{array}$ \\
\hline $\mathrm{b}$ & $\begin{array}{l}\text { Upload the summarized information to the } \\
\text { multimodal transport company. }\end{array}$ \\
\hline $\mathrm{c}$ & $\begin{array}{l}\text { The multimodal transport company informs the } \\
\text { railway container center of the container } \\
\text { optimum volume information. }\end{array}$ \\
\hline d & $\begin{array}{l}\text { The railway container center calculates the } \\
\text { required number of empty boxes and requests the } \\
\text { x station container center to arrange the empty } \\
\text { boxes. }\end{array}$ \\
\hline e & $\begin{array}{l}\text { The } x \text { station container center inform the time of } \\
\text { arrival in railway container center and quantity of } \\
\text { the empty container to the railway container } \\
\text { center. }\end{array}$ \\
\hline $\mathrm{f}$ & $\begin{array}{l}\text { The railway container center informs the } \\
\text { multimodal transport company of this } \\
\text { information. }\end{array}$ \\
\hline g & $\begin{array}{l}\text { Handle insurance and contact the shipping space } \\
\text { of the destination port. }\end{array}$ \\
\hline $\mathrm{h}$ & $\begin{array}{l}\text { The multimodal transport company notifies the } \\
\text { branches to load the goods at the right time and } \\
\text { issue a multimodal transport bill of lading to the } \\
\text { shipper. }\end{array}$ \\
\hline $\mathrm{i}$ & $\begin{array}{l}\text { The goods arrive at customs by road and carried } \\
\text { out one customs and three inspection. }\end{array}$ \\
\hline $\mathrm{j}$ & $\begin{array}{l}\text { The railway container center informs the time of } \\
\text { arrival and quantity of the cargo and empty } \\
\text { container to the Jinan station. }\end{array}$ \\
\hline $\mathrm{k}$ & $\begin{array}{l}\text { After packing the goods, the goods reach the port } \\
\text { of destination (Qingdao or Yantai) by railway. }\end{array}$ \\
\hline 1 & $\begin{array}{l}\text { From the destination port to the destination by } \\
\text { sea. }\end{array}$ \\
\hline
\end{tabular}

\section{Optimization ways of multimodal transport in Shandong area}

\subsection{Strengthening the joint transport of sea rail to promote regional economic development}

In Shandong Province, the coastal ports can establish a waterless port to reach the direct connection of the inland ports through the way of strengthening the sea rail joint transport, and establish a smooth and modern logistics transportation system to enhance the radiation capacity of the port. The circulation of goods will make the hinterland close to the outside world. At the same time, strengthening the connection between the Shandong port and the hinterland area outside the province will also bring new opportunities for the economic development of the hinterland in the province.

\subsection{Establish multimodal transport information platform}


Shandong should set up a multimodal transport information platform at the core of the port. According to the provisions of relevant laws and regulations of port management, the port administrative department should fulfill its rights and obligations in port planning, construction, maintenance, management, and safety supervision. The construction of port information management platform can improve work efficiency and provide more comprehensive and efficient services for port operators, ship owners and shippers. The improvement of the working level of the port administrative department, the construction of the port management information platform, and the exchange of data for other port management departments to provide interface to improve the efficiency of customs clearance.

\subsection{Vigorously develop the freight forwarding agent}

The freight agent understands all kinds of business links, understands all kinds of transportation business and is familiar with relevant laws and regulations. Through the loading and unloading of goods, storage and packaging, the way of transportation, transportation and transportation, the insurance of the goods, and so on, the insurance of the goods is put forward to the client with more correct advice. To assist clients in designing and selecting appropriate solutions so as to avoid unnecessary losses.

\subsection{Improve the level of multimodal transport of container}

To improve the organization level of container multimodal transport, we must: A unified transport management mechanism shall be established, and the renewal of container type should be accelerated, so that the container will be closer to the national standard as soon as possible. Promote the development of information system. To achieve the coordination between technical equipment and container multimodal transport system. As a result, there is still a lot to do in improving the level of multimodal transport of container. Improving the capacity of container organization will play a great role in improving the economic benefit of multimodal transport.[5]

\section{Conclusion}

Shandong province is a coastal province, which is very advantageous to carry out multimodal transport and has achieved relatively satisfactory results in multimodal transport, but it is still far from developed countries. Therefore, Shandong province should be more actively respond to the policies of the state, vigorously develop multimodal transport, improve the original traditional logistics enterprises operating model, and promote longterm and flexible development of the economy.
1. Zhou J J. The necessity of the development of the combined transport of sea iron by the port of sheep port[J]. Water transport management, 2014(4):20-21.

2. Qin L. A review on the development strategy and research evaluation of Marine railway transportation $[\mathrm{J}]$. Logistics science and technology,2017(5):84-88.

3. Wei J G, Rong Z H. Analysis of macroeconomic factors in the development of container multimodal transport in China[J]. Chinese soft science.2000.8

4. Ma Y P. Multiple modes of transport connection operation management and organizational technology research[D]. Chang 'an university,2012

5. Zhang Y L. Shandong will build a multimodal transport development enterprise alliance, and container traffic volume increased by $10 \%[\mathrm{~N}]$. China Network, 2017.

\section{References}

